\title{
Business models that are inclusive of small farmers
}

Bill Vorley (IIED), Mark Lundy (CIAT) and James MacGregor (IIED)

Paper prepared for FAO and UNIDO as background to the Global Agro-Industries Forum, New Delhi, 8 - 11 April 2008 


\title{
Business models that are inclusive of small farmers ${ }^{1}$
}

\author{
Bill Vorley (IIED) \\ Mark Lundy (CIAT) \\ James MacGregor (IIED)
}

\footnotetext{
${ }^{1}$ This paper draws heavily on the work of the Regoverning Markets consortium (www.regoverningmarkets.org) and the associated international conference 'Inclusive Business in Agrifood Markets: Evidence and Action' held in Beijing March 5-6, 2008. Contributions are also acknowledged from the 'New Business Models for Sustainable Trade' project led by the Sustainable Food Laboratory and Rainforest Alliance, 'Inclusion of small producers in value chains' -- a partnership between, Cordaid, Vredeseilanden and IIED; and framework funding to IIED from the Swedish International Development Agency (SIDA). Comments on an earlier draft by Doyle Baker, Carlos da Silva, and Andrew Shepherd, (FAO) and Jose Reijter (Cordaid) are gratefully acknowledged.
} 


\section{Contents}

Introduction

1. Business models and inclusive market development ...................................2

2. What is the business case for adjusting business models in favour of

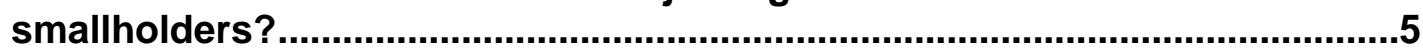

3. What are the various models that have emerged for linking small-scale

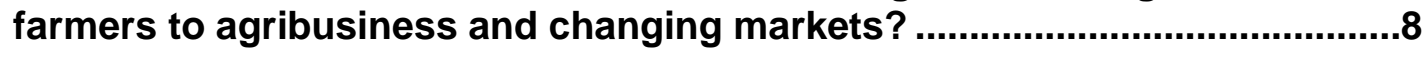

4. How are these models impacting on smallholders? ................................... 17

5. What can be done to help prepare smallholders to participate? ............. 21

6. What do business partners have to consider and do in order to work

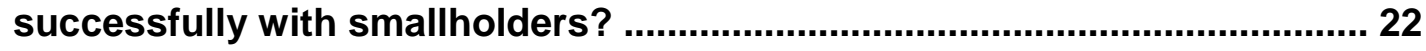

7. What are the priorities for the public sector? ............................................. 24

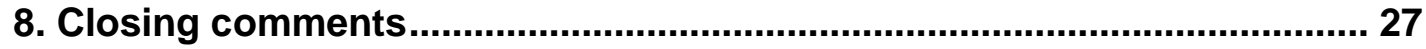

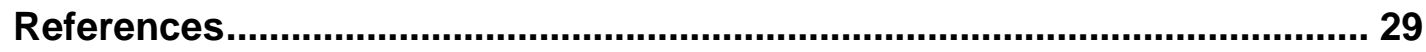

Suggested selected web resources......................................................... 34 


\section{Introduction}

Small-scale farmers, who form the bedrock for global agrifood supply, are faced with markets in an unprecedented state of flux. Domestic markets are undergoing rapid but uneven modernisation, and higher-value and export markets are increasingly the preserve of larger-scale suppliers.

The modernisation of domestic markets, particularly in Latin America and Asia, has been driven by a wave of investments in emerging economies by domestic and transnational food manufacturers and retailers over the past two decades. Combined with rising urbanisation, and changes in consumer preferences and purchasing power, these have led to a growth of modern organised food retailing which has outpaced the growth of percapita GDP by a factor of three to five (Reardon and Huang, 2008).

These changes are generating intense policy debate, particularly regarding the opportunities facing small farmers and the rural poor. The 2008 World Bank World Development Report (WDR2008) notes that in transforming economies where the majority of the rural poor live, "the rising urban-rural income gap accompanied by unfulfilled expectations creates political tensions. Growth in agriculture and the rural nonfarm economy is needed to reduce rural poverty and narrow the urban-rural divide". Those political tensions are clear in India, where the fragmented $\$ 350$ billion retail industry is forecast to double in size by 2015 , and where modernisation and liberalisation of retail foreign direct investment (FDI) have given rise to increased investment coupled with significant protest and policy push-back.

Market modernisation can offer increased economic opportunities for producers, consumers, entrepreneurs, and other actors in the food chain. These opportunities include a reduction in entry barriers to traditionally protected industries, which are further leveraged by clearer information, less capture by elites, stronger access to services, and the potential for entrepreneurial farmers to combine resources and realise the collective worth of their land. In some areas, new market entrants are stimulating competition for farmers' produce, helping to increase the value retained in rural economies. By way of example, the laws which entrenched a monopoly of wholesale markets in India have been amended in at least 14 states, allowing retailers and their agents to procure directly from farmers. ${ }^{2}$ Enforced intermediation through wholesale commission agents had previously hidden the final buyer from farmers.

But there are also risks in opening up markets, where domestic businesses may be bypassed by cheaper imports and where costly market entry requirements favour the better-resourced. These features, which have long been understood in export markets, are becoming a feature of domestic markets in emerging economies as regional trade becomes easier.

If the benefits of modernisation and globalisation are patchy, and do not reach to the 'bottom of the pyramid' to deliver a growth and equity 'win-win', then prospects for meeting the Millennium Development Goals (MDGs) by 2015 are remote. WDR2008 calls for action in response to the modernisation of procurement systems in integrated supply chains and supermarkets, so that small-scale farmers can share in these growth opportunities.

\footnotetext{
${ }^{2}$ See "Modern retail offers wide choice, farmers want to exercise it all." Livemint.com/Wall Street Journal Feb 112008
} 
The failure of major retailers to take such a combined "growth with equity" approach was bemoaned by the late Robert Davies, former CEO of the International Business Leaders Forum (IBLF). He asked "Why are the cleverest logistics and supply chain operators and service companies known in business history sometimes so inept at ... adapting their business model to the sensitivities of emerging markets?"3 Part of the answer - and the subject of this paper - lies in the development of business models which are both inclusive of small-scale producers and also address the need for processors and retailers to manage costs and risks.

Here we define inclusive business models as those which do not leave behind smallscale farmers and in which the voices and needs of those actors in rural areas in developing countries are recognised. Such models have been variously described as "inclusive business" (WBCSD and SNV, 2008; www.inclusivebusiness.org), "mutually beneficial partnerships" (FAO and CIFOR, 2002) and 'inclusive capitalism' (Hart, 2007).

The paper describes a range of business models for inclusive market development within the context of agrifood restructuring and modernisation. It focuses specifically on models that improve the inclusiveness, fairness, durability and financial sustainability of trading relationships between small farmers on one hand and downstream agribusiness (processors, exporters and retailers) on the other. It also alerts us to the needs of external providers, such as financiers and training agents. The gap in basic services in rural economies, such as appropriate extension and credit, needs to be bridged before FDI can live up to its promises. While we do address what producers need to do to compete in modern dynamic markets, and the role of facilitating public policy, our focus in this paper is more on the buyers and their role as partners in development.

\section{Business models and inclusive market development}

\section{What is a business model?}

A business model is the way by which a business creates and captures value within a market network of producers, suppliers and consumers, or, in short, "what a company does and how it makes money from doing it" (MIT Sloan ${ }^{4}$ ).

The business model concept is linked to business strategy (the process of business model design) and business operations (the implementation of a company's business model into organisational structures and systems). Osterwalder (2006) breaks business models up into their constituent elements that create costs and value, with the template in Figure 1.

\footnotetext{
${ }^{3}$ ref.March 2, 2007

${ }^{4} \mathrm{http} / / /$ process.mit.edu/Info/eModels.asp
} 
Figure 1. Template of a business model (adapted from Osterwalder, 2006)

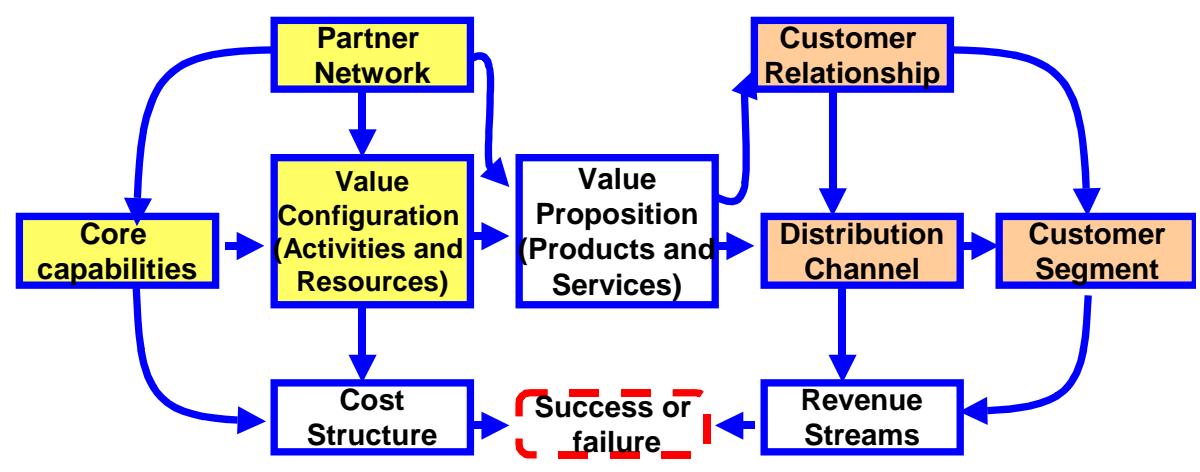

This template shows the importance of market differentiation (building a 'value proposition') and cost management to the success of any business model.

In modern agrifood retail, market differentiation is built on consumer assurance, high standards for food quality and safety, year-round availability, and, sometimes, lower prices that are communicated to consumers through own brands.

It follows that the partner network - the supply chain and its coordination - is a vitally important source of competitive advantage. It also follows that the model is highly sensitive to any addition of costs and risks, and it is around this apex that the question of market inclusivity ultimately revolves.

There are perceived to be high transaction costs and increased risks with purchasing from large numbers of fragmented small-scale farmers. Small-scale farmers are also perceived to be less reliable in honouring trading agreements, because they do not have the technical skills and technologies to produce the right products at the right time (quality, timeliness and consistency). Common business practice sees buyers typically seeking out large-scale suppliers (Box 1) and areas favoured by agribusiness, such as zones involved in export production. This is particularly easy in a dualistic farm structure such as that found in South Africa (Box 2).

\section{Box 1. Carrefour's quality line in China}

Among the supermarkets in China, Carrefour is characterised by marketing fresh foods. With the rising consciousness of consumers on safety of food, the demand for high quality and safe food has increased. In 1999, Carrefour started to sell a "green" food supply line under its own brand with the "Quality Food Carrefour" logo. These lines represent an innovation in the purchasing system within the Chinese context, where Carrefour carries out integrated management of the entire supply chain, with full traceability. Other retailers are following suit. To date, co-operators of the Carrefour quality line are all larger-scale, rather than the small-scale, farmers who account for more than 90 per cent of the agricultural population in China.

Source: Hu and Xia (2007) 


\section{Box 2. From wholesale to preferred supplier: Shoprite}

Shoprite, a leading South African retailer, relied on sourcing from wholesale markets in 1992 for 70 per cent of its produce. In 1992 Freshmark, a wholly owned specialised and dedicated wholesaler, started to form "preferred supplier" relationships with large commercial farmers (from whom it sources the majority of its produce), as well as some large wholesalers and some medium- and smaller-scale farmers. By 2006, it had 700 such preferred suppliers (a few for each main product), and sourced 90 per cent of its produce from them and 10 per cent from the wholesale markets. The shift to using preferred suppliers was facilitated in South Africa by the sharply dualistic farm sector structure. Freshmark has "followed" Shoprite into other African countries, but is still sourcing much of its produce from South Africa.

From the perspective of producers and their organisations, there may be good reasons to avoid trading with the modern agrifood system. With low and inconsistent production volumes, dispersed production, weak negotiating positions, limited capacity to upgrade and meet formal market requirements, and poor access to information, technology and finance, the transaction costs for farmers to link with the modern sector are daunting. And despite significant investments of time and resources, market access is still not guaranteed.

Ultimately, the type of partner network and choice of business model will depend on the nature of the product (perishable, differentiated or branded product, or bulk commodity) and the nature of the end buyer (branded retailer, wholesaler, etc), which determine the nature of economic dependency between chain actors. A collaborative partner network is much more important with perishable commodities such as fresh vegetables, dairy and meat, which require traceability and have higher food safety risk profiles (Sporleder et al., 2005). The same applies to the growing number of certified products, such as Fairtrade and organics. Jan Van Roekel of the Agro-Chain Competence Foundation goes as far as to say that "In the future, agrifood producers, processors and retailers will no longer compete as individual entities. Rather, they will collaborate as a strategic value chain and compete with other value chains in the market place" (Bouma, 2005).

Crucially for the discussion of inclusion of small-scale farmers, these collaborative partner networks, with co-investment and knowledge sharing between producers, suppliers, processors and retailers, are usually built around a small number of preferred suppliers. Adapted business models are called for, whereby small-scale farmers can cooperate to compete as one single supplier, and where their customers are responsive to the realities of smallholder production.

\section{Adapting business models}

When agrifood business models are transplanted from industrialised countries to countries with large agriculture-dependent populations the unintended consequences for the rural economy can potentially be very significant.

In the two largest "transforming" countries, ${ }^{5}$ China and India, 40-60 per cent of the workforce is engaged in agriculture, over 640 million people in total. In Thailand, Turkey and Morocco this figure is 40-50 per cent of the workforce, while in Romania and Honduras agriculture still accounts for a third of employment. The small-scale retail sector also faces major challenges. The Indian retail sector, dominated by 15 million very small independent kirana stores, employs 42 million people, the second biggest

\footnotetext{
${ }^{5}$ One of agriculture's three worlds, according to WDR2008, in which agriculture contributes less to growth, but poverty remains overwhelmingly rural
} 
employer after agriculture. In addition to the lack of inclusiveness and poor awareness of rural economic realities of existing business models, there are other unintended and accidental outcomes. For example, the private standards that buyers have deemed necessary and efficient solutions can compound exclusion of small suppliers given that the costs of such systems are a function of production volume. Put simply, high volume makes standards feasible because the cost per unit of product is low. For many smallholders, however, volumes are low and the unit cost for standards high. This mix can lead to situations where it is financially impossible for smallholders to cover the cost of implementing and maintaining such standards.

It is clear that new business models are needed that afford opportunity in terms of small farmer inclusion and equity and that do not exclude efficient farmers, while promoting business efficiencies. There are potential efficiency gains in developing locally adapted business models that build on the comparative advantage of smallholders, in terms of land, price, farm management, quality and innovation. According to the template of business models above, any adjustments in pursuit of greater inclusiveness must not undermine the most sensitive elements of a model - the cost structure, the value proposition, and the integrity and safety of the product - especially when managing supply from large numbers of small producers.

\section{What is the business case for adjusting business models in favour of smallholders?}

Section 1 has described how the business model of the organised agrifood sector is generally built on the value proposition of consumer assurance, high standards for food quality and safety, low prices and reliability of supply. It set out the biggest challenge for modern agrifood business to work with small-scale farmers as being organising supply to deliver the benefits of logistics, economies of scale, traceability and private sector standards.

While the business case for trading with small-scale producers is being called in to question, experience in the field suggests that a convincing business case for models that are inclusive of small-scale producers can be made beyond efforts to promote corporate social responsibility (CSR), based primarily on securing supply and reducing costs. Table 1 provides a summary of the arguments for and against sourcing strategies for the inclusion of small-scale producers. 
Table 1. The business case for and against procuring from small-scale producers

\begin{tabular}{|c|c|}
\hline For & Against \\
\hline 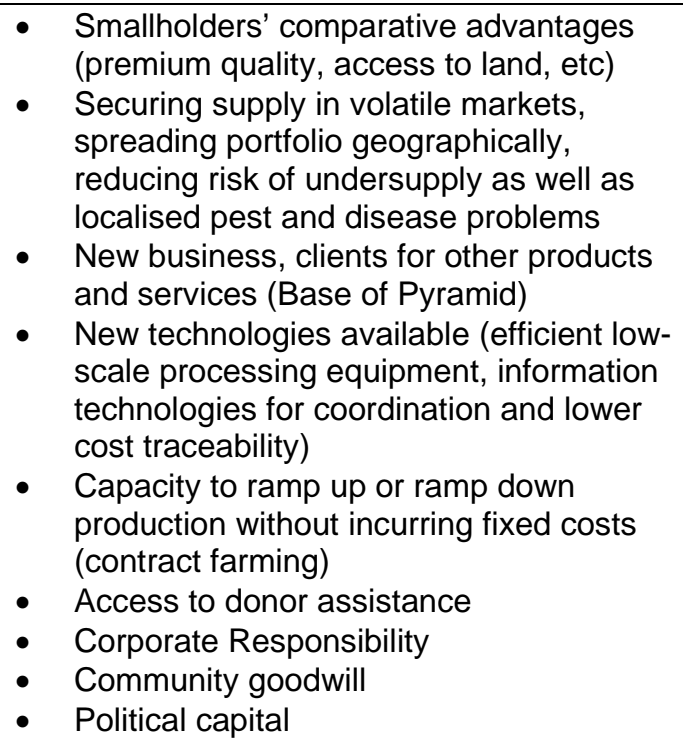 & $\begin{array}{l}\text { Costs and risks in organising supply from } \\
\text { dispersed producers: } \\
\text { - } \text { quantity } \\
\text { - } \text { quality } \\
\text { - } \quad \text { consistency } \\
\text { - } \quad \text { safety } \\
\text { - } \quad \text { compliance with rising standards } \\
\text { - } \text { packaging } \\
\text { - loyalty and fulfilment of commitments by } \\
\text { - } \text { farmers } \\
\text { - } \quad \text { pogotitiation time and cosposition to commercialisation of } \\
\quad \text { peasant agriculture }\end{array}$ \\
\hline
\end{tabular}

\section{Securing supply}

Securing consistent supply is especially critical in supply-constrained and volatile conditions, such as those currently characterising global agrifood markets. A shift from a buyer's to a seller's market implies that suppliers will need to ensure that they can meet their obligations to retailer or processor customers in the face of considerable uncertainty. A diversified supplier base, including small-scale producers, can contribute to improved security of supply.

Retail buyers and processors may also seek to bypass markets where large traders have a stranglehold. This was the situation in Pakistan where a milk processor, Haleeb Foods Limited, worked around the large and well-established milk traders by securing a small-farmer supply base.

An even stronger business case for linking with small-scale producers is where there is a scarcity of alternative suppliers, whether due to the characteristics of the product (seasonality, labour requirements, locality), a shortage of land for large-scale domestic or own-business production, a lack of a medium or large-scale supply base (for example the dairy sector in India or Poland), or where there is demand in remote areas away from main distribution channels (Box 4). 
Tanzania: Given the remoteness of tourist hotels, local supply from small-scale farmers is much less costly, especially during the rainy season when road transportation from outside the area is not always possible. Furthermore, the local supply has a promotional value in the tourist trade as a support to local communities, coupled with the encouragement of environmentally sound production (Mafuru et al., 2007)

South Africa: In contrast to the centralised fresh produce procurement systems of South African retailers, who rely on preferred commercial suppliers, there are also innovative procurement schemes. Two ruralbased supermarket chain stores in the Limpopo Province source fresh vegetables locally from small-scale farmers. By 2004, the Thohoyandou SPAR store was procuring approximately 30 per cent of its vegetables from about 27 small-scale farmers. These farmers are supported by interest-free loans to selected farmers, a guaranteed market, farm visits, and training on required quality standards. The remoteness of the supermarkets from the central distribution centres, the stores' operation in rural areas, reduced transportation costs, and meeting freshness requirements, as well as being seen to contribute to community development, were the drivers for supporting the development of this local procurement scheme from smallscale farmers (Bienabe et al., 2007).

Small-scale producers can also have a comparative advantage in terms of produce quality, innovation, costs and farm management. Indeed, in exports of fresh vegetables from Africa to the UK and from Central America to the US, it is the premium quality products such as French beans and peas that are sourced from smallholders.

\section{New business opportunities}

Small-scale producers are themselves a new business opportunity. In India retailers can now buy direct from farmers rather than operate through the government-controlled APMC wholesale markets. New models of rural retail are emerging, such as the Hariyali Kisaan Bazaar, which combines a "bottom of the pyramid" approach to both the input and output sides of the farm-to-consumer value chain, and is discussed further in this paper. This is an extension of the approach advocated by Prahalad and Hart (2002), which argues that corporations can make considerable profits by designing new business models and products to target the four billion poorest people who make up the base of the economic pyramid.

\section{Community goodwill}

Working with small-scale farmers is also a means to build community goodwill, contributing to a company's licence to operate. Buying locally from smallholders may be part of a company's socially responsible strategy and become an advertising slogan in the highly competitive environment in which it operates. Customers are aware of and may value local procurement from small-scale farmers in the community as long as the produce is of a good quality. The case study from South Africa (Box 3) reported that the retailer arranged for farmers to be present in the store on certain Fridays to promote their small-scale farmer procurement among the consumers.

Other examples of supermarkets working with small-scale producers include programmes by Carrefour in Indonesia, through which dialogue is established between farmers and buyers to ensure increased quality, the development of a "Best Supplier" prize and the waiving of listing fees ${ }^{6}$. In Guatemala, Wal-Mart has recently initiated a programme with an International NGO, Mercy Corps, and the financial service provider AGIL to facilitate the entry of 600 farmers to its supply base over the next three years. The goal of this programme is to guarantee supplies of speciality products as Wal-Mart

\footnotetext{
6 "Carrefour Indonesia takes part in SME programme." www.planetretail.net 1 August 07
} 
expands in the region. Finally, in Mozambique, Shoprite, in collaboration with the IFAD Markets Support Programme (PAMA), has supported the development of small-scale farmers in Boane. Based on this work, Shoprite now sources 25 per cent of its fresh fruit and vegetable needs locally rather than importing from South Africa.

Despite the increasing interest of buyers in working with small farmers, questions remain about the depth of this commitment due to the fragmentary nature of some of these programmes. In Guatemala, for example, Wal-Mart executives have been important allies in the development of a line of personal care products based on medicinal plant extracts produced by indigenous communities in the municipality of Totonicapán. Despite this support, buyers and store-level display managers continue to obstruct the entry of these products in specific stores. The waiving of formal product registry by WalMart executives has been used as an argument by lower-level staff for not including the product in display plans for specific stores, thus effectively keeping the products off the shelves despite high-level support (Lundy and Fujisaka, 2008). This example highlights the tensions and inconsistencies between executive desires and day-to-day business practices. Firms interested in promoting inclusive business models need to pay specific attention to the consistency of both their messages and their practice.

\section{Corporate social responsibility (CSR)}

An increasing number of companies report on their commitments to the development agenda to their customers and shareholders within a wider 'corporate responsibility' framework. The role of business as a partner in development has been a growing element of the CSR agenda, especially since the World Summit on Sustainable Development in 2002, and is promoted by a number of business platforms such as the World Business Council for Sustainable Development (WBCSD) and the Sustainable Agriculture Initiative (SAI), and by a number of UN agencies including UNDP and UNIDO. We are now at a point where 'inclusive business' and CSR part company. CSR, with its emphasis on labour and environmental standards and supplier codes, has been poor at addressing market inclusion, and is often inadequatelly mainstreamed across business. The UN Global Compact, which is the largest global corporate citizenship initiative, has ten principles that address human rights, labour standards, environment and anti-corruption, but they do not address the role of business in supporting the position of primary producers. Some individual businesses and industries have gone further.

A commitment to the development agenda can defend a market. This has been evident recently in the UK, where airfreight of fresh produce from Africa was defended against a strong environmental critique through a clear demonstration of the importance of the trade to rural livelihoods (Garside et al., 2007). However, it remains unclear how significant the commitment is, and whether these early actions will be followed-up by the buyers, consumers or governments.

\section{What are the various models that have emerged for linking small-scale farmers to agribusiness and changing markets?}

The preceding section elaborates the business case for inclusion. However, this will be insufficient to trigger widespread adoption of inclusive business models unless the risks and costs are addressed. Key to overcoming the costs and risks are producer coordination, market coordination and intermediation, service and finance provision, information and knowledge management and buyer behaviour. In this section we address producer coordination and market coordination of small-scale producers. 
Organisation of production is central to overcoming the costs associated with dispersion of producers, diseconomies of scale, poor access to information, technology and finance, inconsistent volume and quality, lack of traceability, and management of risk. In view of the lower transaction costs and the possibility of more effective capacity transfer, private companies often prefer to work with organised farmers rather than individuals despite the increased bargaining power that groups can enjoy. Production may be organised by the producers themselves, by the end customer companies, or by an intermediary such as an NGO, trader, wholesaler, or exporter (Table 2) in a range of direct or indirect market linkages categorised by Shepherd (2007). Organisation might be layered, with buyers operating a continuum from preferred suppliers to top-up suppliers, with an attendant spread of objectives. Typically, success depends on communication flows and constant innovation on both sides.

Table 2. Typical organisation of smallholder production

\begin{tabular}{|c|c|c|}
\hline Type & Driver & Objective \\
\hline \multirow[t]{2}{*}{ Producer-driven } & Small-scale producers themselves & $\begin{array}{ll}\text { - } & \text { new markets } \\
\text { - } & \text { higher market price } \\
\text { - } & \text { stabilise market position } \\
\end{array}$ \\
\hline & Large farmers & - $\quad$ extra supply volumes \\
\hline Buyer-driven & $\begin{array}{l}\text { Processors } \\
\text { Exporters } \\
\text { Retailers }\end{array}$ & - $\quad$ assure supply \\
\hline \multirow[t]{3}{*}{ Intermediary-driven } & $\begin{array}{l}\text { Traders, wholesalers and other } \\
\text { traditional market actors }\end{array}$ & $\begin{array}{l}\text { - } \begin{array}{l}\text { supply more discerning } \\
\text { customers }\end{array} \\
\end{array}$ \\
\hline & NGOs and other support agencies & $\begin{array}{l}\text { 'make markets work for } \\
\text { the poor' }\end{array}$ \\
\hline & $\begin{array}{l}\text { National and local governments eg } \\
\text { via 'Dragon Head' companies in } \\
\text { China }\end{array}$ & - regional development \\
\hline
\end{tabular}

\section{Model development}

Where market linkages are initiated by existing actors, they tend to build on informal structures in which traders or farmer-traders play a critical role, not only to connect farmers to markets but also as de facto service providers. In many cases the trader is a member of the rural community and has specialised knowledge, information, assets and contacts to facilitate not only commercial ties but also social support in times of crisis. Informal linkage models are common throughout the world but little understood. Certainly, knowledge on how to develop business models that leverage these informal linkage systems is scarce. These models rarely receive support from development interventions or attention from researchers due to their informal nature and the strong bias against traders prevalent in many development organisations. This is unfortunate, as these models hold important information and lessons for sustainable market linkages and service provision, especially in areas with weak formal farmer organisation.

Work in Colombia by one of the authors showed that traders are capable of extending market linkage services to smallholder farmers in a sustainable fashion when credit is provided (CIAT and CIPASLA, 2006). In some cases, aspects of trader-driven approaches are adapted by the private sector in lead farmer models, such as those detailed in Honduras (Agropyme, 2006). A key finding is that informal market linkages are a form of cooperation or quasi-cooperation among farmers. For instance, informal moneylenders often hold extensive information about the needs, weaknesses and strengths of their customers, which moneylenders can leverage through supplying or by 
informing suppliers. Importantly, these forms of linkage/ quasi-cooperation are the building blocks for formalised cooperatives.

A more traditional approach is small farmer organisation induced by external agents or a combination of external actors and small farmers. Processes of induced organisations start from the assumption that existing market linkages are not effective either in terms of efficiency or in terms of equity and that new skills and knowledge need to be developed to facilitate favourable market linkages for smallholders. These interventions are often led by development organisations and supported by donors, although examples of private sector initiatives of induced organisation, such as contract farming and outgrower schemes, also exist. Recent work raises doubts as to the sustainability of these induced organisations supported by development actors due to pressures to avoid failure (Berdegué, 2001), unsustainable business practices (Hellin el al., 2007; Shepherd, 2007) and inherent inefficiencies in the intervention model (Berdegué et al., 2008).

Despite the possibly poor performance of induced farmer business organisations led by NGOs and the public sector, there are cases where such interventions are effective especially where the facilitating organisation has a strong business development focus. Of critical importance is a clear and consistent focus on the business case for the intervention as well as a timeline after which external support will cease. An example of this is the work carried out by the Presidential Commission for Local Development in Guatemala which focuses on building 'business ecosystems' to support specific market opportunities. The Commission identifies and links key service providers to the supply chain as for-profit businesses rather than with donor subsidies. The resulting products and services incorporate support costs as part of their overall pricing structure, thus aligning incentives along the chain and increasing the possibility of success as a business (Lundy and Fujisaka, 2008)

Regardless of whether or not the model selected is based on existing actors and skills or is induced, these models can be grouped depending on the focus they accord to diverse actors in the chain. Existing models tend to fall into three general categories: a) those that focus on developing and supporting producer organisations; $b$ ) those that focus on specialised intermediaries; and, c) those that are driven by buyers. Despite the differences in entry points and emphasis, all the models seek to connect actors to facilitate effective market integration.

\section{Producer-driven models}

Producer-driven models such as cooperatives and farmer-owned businesses have had a mixed record of providing members with economic benefits in terms of access to dynamic markets. Research in eight countries (Huang and Reardon, 2008) found that membership of producer organisations was correlated with participation in modern markets in only half of the countries; in the rest the correlation was not significant or was negative. This is indicative of the very diverse roles of producer organisations, from political lobbying to providing channels for government subsidies. Marketing cooperatives are rare, and members typically remain oriented towards the traditional commodity markets. In cases such as Honduras, where they do exist, agribusiness has been averse to purchasing from cooperatives due to slow decision-making and limited entrepreneurial focus (Agropyme, 2006).

But collective action remains an important strategy to increase small-scale producer participation in emerging modern markets and to generate sustained commercial flows of high quality products. Effective business organisation is critical. Economic- and 
business-focused producer organisations differ from welfare organisations in their entrepreneurial orientation and capacities, and may build on existing informal networks of farmers and traders as well as support from buyers or other chain actors. Businessoriented cooperatives and employee-ownership models in Europe and North America provide some insights on how this may be achieved but much remains to be learned from existing informal network models common throughout the developing world. An intriguing, if incipient, case is that of Mabeli S.A. a community-owned essential oils corporation in highland Guatemala where 51 per cent of shares are held by a community development corporation and 49 per cent by producers of the firms raw materials (Lundy and Fujisaka, 2008)

With regard to organisations that are driven and owned by small-scale producers, such as Cuatro Pinos in Guatemala (Box 4) and NorminVeggies in the Philippines (Concepcion et al., 2006; Box 9), a rich range of models exists to allow organisations of producers to collectively market despite membership heterogeneity (in terms of land and non-land assets), which can otherwise lead to conflicts of interest within an organisation. These management models balance member inclusion and group competitiveness, and involve differentiation of membership to cope with the range of land holdings, wealth, education, etc. These include quasi-membership arrangements and top-up suppliers, or clusters around lead farmers, whereby financially independent growers create market opportunities for small-scale farmers. Any member differentiation can be a challenge to the cooperative ethos of equality and equity.

Box 4. Cuatro Pinos, Guatemala
Cuatro Pinos is a successful cooperative with nearly 30 years of experience in the vegetable export
business. Recently the cooperative has succeeded in opening large markets for several fresh vegetable
products in the US through an alliance with a specialised wholesaler and several retailers. Existing demand
significantly outstrips the capacity of cooperative members, requiring the integration of new producers,
organisations and geographies. To achieve this, Cuatro Pinos identifies existing farmer groups, including
associations, cooperatives and lead farmer networks, in favourable environmental niches. It works with them
to test production schemes and then contracts those that show an ability to meet quantity and quality
targets. The cooperative signs a legally binding contract with the producer group, which specifies quantity,
quality and a production schedule as well as providing a fixed annual price for the product. Credit in the
form of inputs and technical assistance is provided. This is later discounted from the first few product
deliveries. Cuatro Pinos provides business and organisational support to its partner organisations to
increase their efficiency and access additional funding from diverse sources for development activities. In
2006, Cuatro Pinos partners successfully raised US $\$ 1.7$ million for investments in irrigation, packing sheds,
education and housing. Through this model Cuatro Pinos has achieved an annual growth rate of 50 per
cent in vegetable exports over the past three years and expanded from 560 member producers to a network
of more than 2,000 families. Nearly all the new producers in the network are from regions with highe-than-
national-average poverty levels and with limited access to land.
Source: Lundy, 2007

Despite the success of Cuatro Pinos and other models, these remain the exception rather than the rule in producer-driven models. Common limitations in farmer organisations include an excessive focus on democratic governance which, in many cases, leads to effective leaders being replaced every 12 to 24 months as stipulated by by-laws. This is avoided in the case of Cuatro Pinos by having a professional management team that reports to the elected cooperative board but is not subject to annual or bi-annual elections.

\section{Buyer-driven models}

Buyer-driven models seek efficiencies in the chain to the benefit of processing and retail. There are some very promising cases where the necessity of organising supply from a small farm base, often the case with milk procurement, for example, has led to sustained inclusion of small-scale farms. 
The classic model is where the buyer integrates backwards and coordinates production (see Boxes 2, 3, 5 and 6). Both the producer and buyer ends of value chains usually want to "cut out the middleman" and want more competitive buying markets in order to make a shift from a dependency on traditional wholesale markets in pursuit of value, improved quality, and product assurance. Direct procurement is often presented as a win-win-win for customers, business and producers. Improved information flow among the supply chain segments can also help reduce the marketing risk faced by both the company and farmers. Another reason for businesses to organise their own supply base is the lack of collective action by producers, often due to suspicion of cooperatives or laws that insulate producers from the market by obliging farmers to trade through local government-controlled wholesale markets, such as the APMC Act (law governing the marketing of agricultural products) in many Indian states and the Wholesale Markets Law in Turkey.

\section{Box 5. Dimitar Madzarov in Bulgaria}

The private Bulgarian dairy processing firm, Dimitar Madzarov Ltd., has increased by a factor of 20 its daily processing of milk, sourced from over 1,000 small farms, half of which have fewer than five cows. The firm has successfully met all the requirements to continue selling its dairy products in a demanding and highly competitive market. Part of the success of Madzarov in building a reliable milk procurement system has to do with the high frequency of payment to its small-scale farmer suppliers. In the case of the smallest farmers, the firm goes as far as advancing payment. Access to this source of timely and reliable financing is considered by the farmers to be of greater importance than the price received for their milk.

Source: Bachev and Manolov (2007)

\section{Box 6. MA's Tropical Food Processing (Pvt.) Ltd., Sri Lanka}

MA's Tropical Food Processing (Pvt.) Limited, established in 1987, is a family-owned spice processing enterprise in Sri Lanka, which has shifted its focus to a centralised procurement system. The centralisation process has increased the efficiency of procurement through the reduction of the coordination cost.

Procurement is centred on the Regional Agribusiness and Perennial Crop Initiatives and Development (Pvt) Ltd (RAPID), which is responsible for the backward integration of the company's activities in the supply chain and for delivering its social responsibilities to the region. It provides extension services to the farmers for production, record keeping and post-harvest practices, organic certification, supply of high quality planting material and intermediation of commercial credit from banks. It assures continuous supply of raw material at the right time in the right quantity and quality and "eliminates non-essential intermediaries" from their supply chain. It has resulted in improved information flow among the supply chain segments while reducing the marketing risk faced by both the company and farmers.

The company sets its own private standards, which facilitate the standardisation of the products procured from different suppliers and differentiate the company's products from competitors. Further, the company offers farmers a considerable adjustment period to bring the produce up to the standards and pays premium prices to farmers who meet those standards. The company focuses on moving towards logistic improvements in the supply chain by introducing new operations which have not existed earlier in the areas of grading, processing, packaging, labelling, trademarking, etc. Those practices have made the company more competitive in the local and international markets, enabling its products to satisfy the newly emerging trends in consumer preferences.

Source: Samaratunga (2007)

Another example of a buyer-driven model from Sri Lanka is the supermarket company Food City. This retailer has a high market penetration for food by South Asian standards (15 per cent), with nearly 120 stores, and a focus on middle and low income consumers. Like MA's (Box 6), the management of Food City has a strong commitment to the reduction of rural poverty through its role as purchaser of quality products. The company has made investments in backward linkages (fruit, vegetable, rice and milk) and food 
processing (meats, ice cream and processed fruit and vegetables). Food City is now looking at regional expansion in Pakistan and Bangladesh.

Given the difficulties faced by producers in Turkey to organise themselves, the few cases of successful direct relations between supermarkets and producer organisations are largely implemented and promoted by supermarkets. For example, Migros Türk achieved direct sourcing with the Narlidere Village Development Cooperative in the Bursa region where others failed, only because of its historical background and its anchoring within the Turkish agrifood chain. Migros invests in capacity building of its supply cooperatives' staff and supports production management, thus going far beyond the incentives contained within formal contracts (Lemeilleur and Tozanli, 2006).

Contract farming can be successfully used by businesses to link small-scale producers to modern markets where capital, technology and market access constitute key limiting factors (Eaton and Shepherd, 2001, FAO, 2008). Contracts provide benefits to traders and processors by removing the risk of periodic shortages and volatile prices, which can be costly if they are servicing large downstream contracts written in advance of a season (Hayami and Otsuka, 1993), or by allowing access to land which may not be available to expand plantation-scale production. Contract farming can also be an effective mechanism for risk management, because a well run contract scheme with proven production technology and guaranteed markets can help reduce risks normally faced by unorganised farmers, as seen in the case of Cuatro Pinos in Guatemala in Box 4. For farmers with small landholdings, a contract can also be used as guarantee for loans; there are a growing number of providers of finance, such as Root Capital, ${ }^{7}$ who are prepared to provide cash flow credit to smallholders who have secure contracts in place.

Organisation of producers is just as important for contract farming, as management and enforcement of contracts with individual smallholders is not viable. Research from the Indian Punjab shows that companies involved in contract farming prefer to work with medium- and large-scale producers to reduce their transaction costs and ensure quality standards (Sharma, 2007). Enforcement of contracts with small-scale producers is a thorny issue, especially when market prices exceed the contracted price. Often, having market 'contacts' with whom agreements can be brokered with a reasonable expectation of compliance is more important than a legally binding but difficult to enforce formal contract.

Contract farming can be an intermediate step in the commercialisation of small farmer production, as farmers innovate and reconnect with more traditional system of brokers, but on their own terms. This is the case with potato production in northern Thailand (Wiboonpongse et al., 2007).

\section{Models of intermediation}

Integrating forward (for producers) or backwards (for retailers or processors) is timedemanding and expensive. Business models transferred from the elite retail-driven chains may be as inappropriate for agribusiness as they are for small-scale producers. Despite the attractions of "cutting out the middle man," organising direct procurement can have high transaction costs for private players, and have mixed outcomes. In Mexico, Wal-Mart recently tried to buy strawberries direct from the farmers, but withdrew due to high costs (Berdegué et al, 2008b). Given these costs, a business model that

\footnotetext{
${ }^{7}$ Root Capital is active in 29 countries in Latin America, Eastern and Western Africa and Asia (http://www.rootcapital.org/where we work.php)
} 
works with chain intermediaries, either traditional or new, can offer the opportunity to be profitable in highly competitive, price-sensitive markets.

It is much easier for retailers setting up in emerging economies to procure from traditional wholesalers, and leave the wholesaler to grade for physical quality, unless there are strong market incentives for retailers to guarantee product quality, consistency, safety and traceability. This explains the relative scarcity of evidence of farm-level restructuring and the type of model described in Box 1 in developing and emerging economies (Huang and Reardon, 2008). The economics of backwards integration are particularly daunting in Chinese horticulture: the market is characterised by 50 million autonomous producers, selling on spot terms through five million small traders; the retail market is very competitive and few companies are making money; and the majority of customers are not willing to pay for top-class produce. Although many supermarkets profess to be putting vertical coordination in place, the majority of trade is via traditional traders.

There are, however, some very promising models of upgraded or new intermediaries that are introducing food safety, consistent quality, year-round supply and innovation, at a competitive price. Private companies are emerging as important intermediaries that enable small-scale farmers to supply to supermarkets, as exemplified by Bimandiri in Indonesia (Box 7) and Hortifruti In Honduras (Box 8). Another example is the production network for hot peppers managed by the export firm, Hugo Restrepo and Company, in Colombia and Peru. Under this model, the firm provides services to farmers, such as access to seeds, drip irrigation technology and technical assistance, as well as a guaranteed market via contracts to participating producers, producer organisations, and clients involving quality control and guaranteed volumes (Ochoa and Lundy, 2001). While this is not an exclusively smallholder model, it shows the range of services that a specialised intermediary organisation can provide.

\section{Box 7. Specialised wholesaler: Bimandiri in Indonesia}

The Bimandiri company in Indonesia, which has changed from a traditional wholesaler to a supplier of vegetables and fruits mainly to Carrefour, is an example of a specialised intermediary. Bimandiri encourages farmers to cooperate in producer organisations and works with those groups on the basis of agreed quantities. The company has worked closely with its producer organisations, supplying technical assistance and credit, in order to assure quality standards and consistent volumes for its retailer client. Bimandiri has maintained preferred suppliers lists but moved away from a close extension role. It continues to implement transparent negotiated producer prices.

Sources: World Bank (2008); Sandredo (2006).

As is clear from the examples of Bimandiri, Hortifruti and Hugo Restrepo, models of intermediation include a strong dose of service provision, including finance - usually by the intermediary organisation or specialised providers - to balance the needs of both small-scale farmers and the realities of emerging modern markets in terms of quality and volume. For example, the Los Angeles Salad Company, which works as a wholesaler between Cuatro Pinos in Guatemala and the retailer Costco in the US, not only helps to market products and provides logistics support in the US but also provides technical assistance in product quality, access to innovations in packaging and packaging technology, and assistance in new product development. The company also helps facilitate production planning and manages over- or under-production in coordination with other producer regions. Without the provision of these services, the ability of Cuatro Pinos to sell consistently to Costco would be much weaker. These new intermediaries are characterised by increased knowledge management (to improve chain coordination and quality), closer links to buyers, and incentives for product and process upgrading. This can be an important new role for NGOs, though there is a growing appreciation of the efficiency benefits of upgrading existing intermediaries. 
A new generation of commercial intermediary in India is demonstrating that service provision can itself be a profitable part of the business model, which can trigger inclusive growth. The rural retailer, Hariyali Kisaan Bazaar, which is part of the DSCL conglomerate, sells agri-inputs and consumer goods through its chain of centres, which also serve as a common platform for providers of financial services, health services, etc. The Haryali centres are procurement hubs for farm outputs, providing buyback and warehousing (Bell et al., 2007b; Gupta, 2008), and thus creating multiple revenue streams based on transparent and effective participation in input as well as output value chains. Each Hariyali store has a catchment radius of 20 to $25 \mathrm{~km}$, comprising about 1520,000 farming families. They aim to provide producers with "urban amenities in rural areas", easy availability of quality products at "city-like" fair prices and, through IT, provide commodity prices and commodity futures, as well as ATM access and weather forecasts. On the procurement side, they create linkages between producers and processors, exporters and retailers.

\begin{abstract}
Box 8. Lead farmer networks with Hortifruti Honduras
Hortifruti is the specialised wholesaler for fresh fruit and vegetable for Wal-Mart in Central America. The company works with a variety of suppliers for vegetables in Honduras and Nicaragua, often purchasing product from existing farmer cooperatives. However, it has experienced significant difficulties with these farmer organisations in terms of lengthy decision-making processes. As a result, Hortifruti Honduras has developed and promoted a 'lead farmer' model of organisation through which it identifies and builds the capacity of farmers who can meet its quality needs in a consistent fashion. After demonstrating such capacity, lead farmers receive larger and larger orders for product or new products and are invited to work with neighbouring farmers to meet this demand. Lead farmers provide access to technology, technical assistance and market access to their network of neighbours as part of a bundle of production and marketing services. The cost of these services is recouped via the sales margin to Hortifruti. The expansion of this model depends on the identification of new lead farmers. Early results indicate that it is low-cost, scaleable and sustainable.
\end{abstract}

Source: Agropyme, 2006; Lundy, 2007

There are examples of producer organisations adding their own commercial intermediary, in the form of consolidation and marketing units (Box 9).

\title{
Box 9. Normincorp in Mindanao, Philippines
}

Farmers of the Northern Mindanao Vegetable Producers' Association, NorminVeggies, are able to successfully participate in dynamic vegetable chains primarily because of the organisational structure they chose in order to respond to the market challenges. This involves a corporation, Normincorp, which gives them the agility needed for each development in the supply chain. Normincorp's formation signified a new development in marketing for small farmers. While established as a stock corporation, Normincorp functions more like a cooperative and has a social enterprise character. It was a set up and operated with keen business sense but also with full empathy for the small farmers. As market facilitator, Normincorp saw to it that production was programmed by farmer clusters with their respective cluster leaders, according to marketing plans; that quality farm and post-harvest management could be done by each farmer in the cluster; and that coordination could be provided for the sequence of activities that include order taking, outshipment logistics, billing/charging, collection and remittance to the farmers. For these services, Normincorp earns a market facilitation fee based on the value of the sale and uses the income to cover the marketing management overhead.

Normincorp is not a trading company. Rather, it is a market facilitator linking the farmer through his or her cluster directly to the buyer. The farmer is given the buyer's price, and s/he is therefore accountable for the product and retains ownership of the product up to the point of sale. This encourages the farmer to supply the best quality since the price is given to him/her and all sales are remitted directly after deducting the market facilitation fee, which is based on the quantity of accepted vegetables. Conversely, all rejects are individually charged to the farmer concerned. Labelling of products per farm or farmer provides this traceability.

Source: Concepcion et al., 2006 
Working with this new generation of "doubly-specialised intermediaries" (which are both business-oriented and development-motivated) such as Normincorp appears to offer the greatest potential for linking large business with small-scale producers.

Much more common at present is market-oriented but traditional traders taking steps to improve quality in their supply chains, where suppliers produce to the traders' specifications (crop management, harvesting, packaging, etc), and where the traders invest in supplier training and other investments. A very interesting example of a butterhead lettuce supplier to Ho Chi Minh City in Vietnam has been identified by Cadilhon (2006). The farmer collectors who supply the intermediary train farmers to grow and harvest high quality lettuce. Through this collaboration, and through investments and forward planning with regular suppliers, the intermediary only gets high quality product. In China, agricultural brokers and traders were denigrated for several decades and the government tried to ban them, but without success. The government realised the vital role that an agricultural brokers' association can play as a bridge between small farmers and outside markets, and in contributing to farmers' incomes and rural development. It therefore it adopted a new strategy designed to organise them and regulate their activities after the economic reform (Shudon, 2008).

Export-oriented companies setting up in new supplier countries almost always rely on intermediation to simplify decision-making, reduce risk and lower transaction costs.

\section{Alternative trade models}

Alternative trade models cover a range of initiatives that make use of third party certifications to monitor compliance with selected indicators valued by diverse members of the supply chain. Alternative trade models can be divided by their principal focus. For the purposes of this paper, we will briefly discuss standards that seek to promote benefits to the local economy and community and how they seek to resolve the issue of business models. We use Fairtrade as a model of what is, admittedly, a much wider pool of alternative trade standards. ${ }^{8}$

Of the existing alternative trade models, perhaps the best known is the Fairtrade movement which has the objective of creating opportunities for economically disadvantaged producers as its strategic intent. Is there then, in Fairtrade, a shortcut to inclusive markets? Is Fairtrade a valid business model for large companies to translate into their mainstream trading, or at least a source of elements for new business models?

Fairtrade has at its core the concept of "fairer" pricing that gives growers in developing countries a better price for their work and gives longer term stability to producer-buyer trading relationships. The umbrella organisation Fairtrade Labelling Organizations International (FLO) stipulates two sets of generic producer standards, one for small farmers and one for workers on plantations and in factories. The first set applies to smallholders organised in cooperatives or other organisations with a democratic, participative structure. The second set applies to organised workers, whose employers pay decent wages, guarantee the right to join trade unions and provide good housing where relevant. On plantations and in factories, minimum health and safety as well as

\footnotetext{
${ }^{8}$ Other relevant standards that speak to small farmer viability include SCS-001, Basel Criteria for Responsible Soy, Rainforest Alliance, the Roundtable on Sustainable Palm Oil and the SAI Principles and Practices for Sustainable Production. However, many certification schemes do not contain elements of business models which may be considered as central to inclusion of small-scale producers, such as transparency (including transparency of how the certification premium is allocated), collective action, durability of trading relationships, etc.
} 
environmental standards must be complied with, and no child or forced labour may occur.

As Fairtrade is also about development, the generic standards distinguish between minimum requirements, which producers must meet to be certified as Fairtrade, and progress requirements that encourage producer organisations to continuously improve working conditions and product quality, to increase the environmental sustainability of their activities, and to invest in the development of the organisations and their producers/workers.

The standards stipulate that traders have to:

- $\quad$ pay a price to producers that covers the costs of sustainable production and living;

- pay a premium that producers can invest in development;

- partially pay in advance, when producers request it;

- $\quad$ sign contracts that allow for long-term planning and sustainable production practices.

Finally, there are a few product-specific Fairtrade standards for each product that determine such things as minimum quality, price, and processing requirements, These have to be complied with.

Some elements of the Fairtrade model - such as commitment to long-term trading relationships - are cornerstones of inclusive business. But, as a business model for wider application, there are a number of limitations, some of which are easier to resolve than others. There are deep tensions between the smallholder and plantation standards, and the lack of a clear definition of 'disadvantaged producers and workers' based on access to markets as well as income. In contrast to pricing models which are based on a combination of market conditions and product quality, Fairtrade floor prices are fixed by FLO, and have proven slow to change even in sectors where significant market price increases have occurred, such as coffee.

For many large companies, Fairtrade accounts for a small proportion of their overall purchases. Many food retailers have positioned Fairtrade as an up-market niche, as a test of their customers' willingness to pay for "non-exploitative" trading with primary producers, rather than as a corporate standard and a means to transform their mainstream businesses (Tallontire and Vorley, 2005). Even within the Fairtrade movement, questions are being asked about whether the purchase of certified Fairtrade goods is an effective way of achieving systemic fairness in trade. These groups are investing in other approaches such as in schemes to facilitate improved access to conventional markets for marginalised producers, and lobbying on codes of practice on retailer-supplier trade relations.

\section{How are these models impacting on smallholders?}

Impacts of different business models on smallholder farmers vary depending on the model employed and the way this is implemented by the chain actors. As the business axiom states, "you can't manage what you don't measure" and increasing attention is being paid to the development of tools to assess the impacts and sustainability of diverse business models. The paper Inclusive Business by World Business Council for Sustainable Development and SNV Netherlands Development Organization (WBCSD and SNV, 2008), distinguishes between direct economic benefits, indirect economic benefits, and broader social benefits. Recent academic work highlights considerable attempts at developing metrics for supply chains but none has been fully implemented (Aramyan et al., 2006). The area of key performance indicators for supply chains 
remains under development and is limited by a lack of transparency and cooperaton among supply chain actors (Van der Vorst, 2006). Despite these limitations, it is clear that business models have both quantifiable and qualitative impacts on smallholder farmers. Both categories need to be measured and assessed to understand the effects of the business model on rural populations.

The first category are key 'quantifiable indicators', which are focused on measuring chain-wide evolution. Those indicators relevant to smallholders include production volumes, product quality, net income, distribution of income among smallholders, within households and along the supply chain, as well as the distribution of costs associated with risk mitigation and management. These indicators can be complemented by additional quantitative measures that assess the overall 'health' of the supply chain, such as market position and penetration, profitability as compared to similar chains, and trends in volume and prices.

A second critical area of impact assessment focuses on 'qualitative or skills-based indicators'. While difficult to quantify, advances in skills and relationships underpin and sustain gains shown in quantifiable indicators such as income and profit. Key skills related to the quality of the trading relationship focus on negotiation, the construction of sustainable commercial relationships and the governance functions of the chain itself. For chains linked to dynamic market segments, additional attention should be paid to issues related to product and process upgrading and collective innovation as the chain adapts to increasingly demanding market conditions. While this process does not occur fully at the farmer level, the existence of this skill set is critical for continuing competitiveness of the overall system. Unlocking innovation and opportunities for smallholders is a critical element of impact since this leads to benefits that help drive farmer incentives for inclusion.

Changes achieved through producer organisation models can improve negotiating skills and enhance access to service provision. Models of producer-driven vertical integration - becoming co-owner of a supply chain or one of its segments in pursuit of value-added - can make sense when built on a business mentality. However, this downstream ownership route may not always compare well to investments in building a network of specialised actors to achieve similar goals. For instance, research in Africa provides interesting evidence in this regard, showing that many of the benefits achieved by relatively autonomous smallholder-owned and -managed cooperatives can be captured by more dependent, i.e. less highly trained and skilled, groups if appropriate links are developed with other market actors (Stringfellow et al.,1997). The argument for choosing a strategy of vertical integration versus horizontal cooperation may, therefore, boil down more to costs (money and time) than notably different outcomes.

Some arrangements to sustain the inclusion of all members while maintaining the competitiveness of the organisation, such as lead-farmer clusters, which accept differentiation within organisation based on assets, are a significant and challenging departure from the original cooperative ethos of equal treatment for all members. Cuatro Pinos (Box 4) exemplifies this tension. Despite the success achieved in expanding a supply network by nearly 400 per cent while maintaining high product quality, the final distribution of benefits is still skewed towards cooperative members as opposed to nonmembers, although non-members provide up to 80 per cent of product volume in some categories. Farmers who do not happen to live in the seven communities where the cooperative was founded 30 years ago are not allowed to become members. This means that they cannot access profit-sharing mechanisms developed by the cooperative that provide significant additional income to producers at the end of the year. Cuatro Pinos' management is aware of this issue and is seeking to resolve it through service provision and increased prices and/or volumes from non-cooperative members. 
However, it is members themselves who would need to reform their organisational rules to allow the inclusion of new members (Lundy, 2006). To date, this has not happened.

Models focused on intermediation drive change through processes of negotiation among actors. They achieve efficiency gains through greater organisation along the whole chain through improved information flow and shared standards. The distribution of additional benefits along the chain needs to be negotiated and care needs to be exercised in not allowing the intermediary actor to extract additional benefits based on information asymmetries. The development of transparent pricing mechanisms is an important tool to reduce this risk. For example, in Indonesia, the specialised wholesaler Bimandiri (Box 7), which supplies fruits and vegetables to Carrefour operates a transparent margin system to cover its participation in the system. All actors know the final prices and the intermediary margin, thus avoiding windfall profits for the intermediary organisation when market conditions improve and providing an incentive to increase volumes. In other cases, prices are set based on crop models on a yearly basis. This can be done with producer participation, such as in Cuatro Pinos in Guatemala, or a non-participatory fashion, such as in the case of Hugo Restrepo and Company in Colombia. Regardless of how prices are set, clarity on how prices reflect production costs, relative risks and returns is critical to assure greater equity along the chain.

Buyer-driven models affect smallholders through the application of (often strict) norms and standards relating to quality and volume. They tend to push processes of functional improvement up the supply chain, often with limited incentives to compliance beyond continued participation in the market. Because of their proximity to the end buyers, these models can identify consumer trends and can provide clear incentives for marketdriven product and process upgrading. Additional benefits tend to accrue to buyers and care should be taken to achieve transparent assessments of gains and meet equity concerns.

Cases of inclusion driven by private businesses are characterised by small farmers having less say in the governance of the chain and by less capacity building of smallscale suppliers beyond production and post-harvest management. Where a buyer organises a network of producers from a Corporate Responsibility ethic, the risk is more one of paternalism and dependence. On the other hand, case study analysis (Berdegué et al. 2008) found no evidence that in such situations small farmers will have lower direct economic benefits, at least in the short run. Also, under these conditions small farmers do not need to incur the costs of coordination or of collective action. In the case of MA's in Sri Lanka, there were clear income benefits for smallholder suppliers (Box 10).

A buyer-driven network can be managed through using the transparent pricing strategies highlighted above as well as the incorporation, where possible, of incentives based on quality. For example, the US speciality coffee company Intelligentsia Coffee and Tea manages a 'direct relationship' quality-based model with producers. This model prices coffees based on their cup quality, with payment going directly to the producer. Additional services needed to move the coffee from the farm to the US market are contracted by Intelligentsia directly and not discounted from the farmer price (New York Times, 2006). 
An impact assessment of the smallholder procurement system established by MA's Tropical (Box 6) showed clear improvements in corporate income, volume of trade, assets, farm income, employment creation and non-monetary benefits, while ensuring a greater degree of inclusion of small farmers in the new supply chain. With inclusion in the company's supply chain, the farmers achieved a premium price for better quality products, price stability, a spread of income throughout the year, and services such as extension, credit facilities and marketing risk minimisation.

$\begin{array}{ll}\text { Average yearly per acre income comparison (Rs/acre/yr) } \\ \text { Farmers supplying to MA's } \quad 98,000 \\ \text { Non-supplying farmers } & 48,000\end{array}$

Price comparison between MA's and village trader $(\mathrm{Rs} / \mathrm{kg})$

$\begin{array}{llllll} & \text { Cinnamon } & \text { Nutmeg } & \text { Cloves } & \text { Pepper } & \text { Citronella } \\ \text { MA's } & 675 & 300 & 580 & 180 & 22 \\ \text { Village trader } & 550 & 150 & 360 & 125 & 12\end{array}$

This model has been in existence as a sustainable system for about a decade. While increasing its capacity for greater inclusion of farmers, the company has not yet reached its potential capacity.

However there is some evidence of exclusion through the higher transport charges, delayed payments, use of cheques as the mode of payment, and the low production capacity of the company. Even though the company has initiated an informal farmer organisation, lack of coordination and poor structure has excluded a certain strata of farmers from the system. Lack of quality consciousness and credit-bound relationships with the village traders also have some form of correlation with the exclusion of farmers from the chain.

Greater inclusion can be attained by creating an arrangement for the transport costs to be borne by the company or farmer organisation and by introducing a liquid method of payment.

Source: Samaratunga (2007)

A drawback of buyer-driven models for producers is the frequent demand for exclusivity. From a processor or retailer perspective, a supply chain is a source of competitive advantage, and they will seek to exclude competitors and prevent suppliers from 'side selling'. Because a buyer has invested in the supply network, and because the buyer needs to able to fulfil contractual obligations for specific volumes to its customers, it will demand exclusivity from its smallholder suppliers. This can be frustrating for producers, who do not see transparency in how prices are set, or in how quality discounts are often determined. The Kenyan supermarket Uchumi makes a point of not demanding exclusivity from its smallholder suppliers. Another way around this issue is to have prices set weekly rather fixed at the start of the season, to reduce discrepancies between contract and market prices (Box 11).

Alternative trade models, especially Fairtrade, have demonstrated success in benefitstransfer and consumer acceptance. Nonetheless, an important percentage of the Fairtrade premium resides with certification and coordinating agencies. Gross margin at retail level is much higher than at other levels of the value chain. Consequently it has been argued that consumers of Fairtrade products are supporting the shareholders of the international retailers more than the actual smallholder target groups. Incentives for product improvement and innovation have been traditionally weak, with limited feedback regarding consumer trends and demands beyond that covered by certification.

None of the above business models is inherently superior for smallholders, with the possible exception of classical Fairtrade. To initiate processes quickly, intermediary or buyer-driven models are useful as they provide turnkey solutions and somewhat lower risk. In the medium term, however, the promotion of stronger producer organisations may build greater resilience and increased participation in chain governance, especially if combined with specialised intermediaries. 
The selection of a specific model or elements from various models is highly dependent on market conditions, participating actors and their knowledge and skills and the existence (or not) of support agencies and policies. As market linkages evolve, models need to adapt to respond to changing market conditions as well as in the relationships between the participating actors. Approaches need to be piloted for specific locations, products, conditions and markets in order to better understand how to update current models, and which forms of best practice need to be adapted to help support sustainable impact for smallholders.

\section{What can be done to help prepare smallholders to participate?}

From a business model perspective, what needs to happen at the farm level and in supply chains to support the participation of small-scale farmers in dynamic and more profitable market segments,?

According to a study of 35 successful farmer-owned rural businesses in Latin America (Camacho et al., 2007), producer organisations follow a similar trajectory of skill development that includes capacities focused on: (a) market linkages for goods and services; (b) increased internal social capital; and (c) the development of professional management capacities. The development of these skills requires access to effective business support services, effective alliances with other chain actors and an effective enabling environment.

Support services may be technical, managerial or financial in nature, provided by diverse types of formal and informal service providers. But they share several common factors: (a) a focus on effective solutions to bottlenecks that cause exclusion; (b) a business orientation to guarantee sustainability over time; (c) flexibility linked to client needs; and (d) provision by operators close to the clients. The topic has been covered in depth in the Business Development Services (BDS) literature. ${ }^{9}$ For many smallholders, service provision between commercial actors, known as embedded services, holds promise in that these services depend on commercial incentives rather than public subsidies.

Financial services are crucial for farmers to access dynamic markets and sustain their participation in them. As supermarkets and processors tend to pay only after a certain period (often 45 days or more), there needs to be a mechanism to bring liquidity into the supply chain. In addition to working capital provision, other financial services such as cash flow finance, in which the commercial relationship rather than collateral assets guarantee the loan, can be arranged as three-way agreements between buyer, producer and finance institution. The informal moneylender is likely to guard customer information on risk and viability. One option is to transform the moneylender into a bank worker. This has been proposed by some NGOs and external funders, but there has been patchy success with this. A version of this transformation rewards knowledge and innovation by the moneylender through private sector arrangements.

There are often good reasons for a lack of embedded services in rural areas. Successful services rely on knowing the customer well. Research shows that this knowledge is difficult for non-residents to obtain or interpret. Using tools that strengthen the capacities of informal service providers to identify, provide and improve their embedded services in rural areas is critically important.

\footnotetext{
${ }^{9}$ www.bdsknowledge.org
} 
A crucial point in times of high and volatile market prices is the development of models of 'reciprocal responsibility' between buyers and producers. As prices and demand rise, producer organisations will be tempted to break contracts and side-sell committed volumes to other buyers offering higher prices. This might generate additional income in the short term but it is critical to recognise that sustainable relationships can generate additional negotiation power in the long run. In addition, sustainable relationships lay the groundwork for the development of joint ventures for new product development and coinvestment. Opportunistic behaviour works directly against this possibility.

The above interventions must link to a suitable enabling environment, the components of which are described in more detail in Section 7.

\section{What do business partners have to consider and do in order to work successfully with smallholders?}

We have seen in Section 1 that the biggest challenge for large businesses in working with small-scale farmers is that of organising supply. Without a means to reduce transaction costs, ensure due diligence, and ensure that trading agreements are honoured, they will see smallholder suppliers as a threat to their 'value proposition'. In Section 3 we saw that there are many examples of companies organising their own supply base and setting up producer groups, especially where there is a lack of collective producer action. But organising direct procurement is costly for private players, and such efforts are likely to remain as small CSR pilot projects. Where there has been positive business action, it has largely focused on niche export markets to the North rather than the much more pressing challenge of inclusive development within 'transforming economies' where 80 per cent of the world's rural poor live.

Opportunity lies in the 'Partner Network' part of the business model template in Figure 1. Much private sector policy is rooted in procurement-profit philosophy, without extending this approach to co-investment or partnership win-wins. A suggested refocusing of private sector innovation and incentives on sustainable supply from small-farmer networks has the potential to unleash the best of all worlds.

\section{Upgrading mainstream procurement}

Much can be done by businesses to upgrade mainstream procurement within their existing model to ensure that their procurement practices work to the benefit, rather than detriment, of small-scale producers and suppliers. The clear business incentives are continued access to supply, option to be the 'buyer of choice', access to better quality supply and a social license to operate. Points of focus here are coherence between corporate policies and actual procurement practices, through adjustment of reward systems for buyers, and through senior management buy-in. A reorientation of training and development awareness of buyers is a first priority. The asymmetries of market power between sellers and buyers have, until recent food price rises, allowed retailers to simultaneously extract both lower prices and higher standards from suppliers. Traidcraft's reports on purchasing practices are an excellent source of further information (eg CIPS and Traidcraft, 2008). Payment terms and contracts can be adjusted to the realities of smallholder production without compromising commercial imperatives (Box 11 and Box 12). Buyers are quick to criticise 'side-selling', but may readily engage in 'side-buying', procuring opportunistically outside of established supplier networks for short-term profit. 


\section{Box 11: Adjusting Payment terms: Vegpro in Kenya}

In common with other leading exporters of fresh vegetables from Kenya, Vegpro divides production between its own farms and smallholder outgrowers, on which it relies for crops which are not well suited to plantation production, such as peas. In 2007 Vegpro was purchasing most of its snow peas from 3,500 smallholder farmers organised into 50 self-help groups. Despite the coordination offered by the self-help group structure, it is no small task to ensure consistent volumes, quality and standards across 3,500 farmers. Vegpro had previously been paying farmers a fixed year-round price that exceeded the average market price over the course of the year. When the market price was below the fixed price, farmers had been content to sell to Vegpro, submitting volumes that apparently included uncertified produce from their neighbours. But when the market price rose, farmers in need of cash would side-sell to local traders. Vegpro reduced side-selling by employing field supervisors and switching from annual fixed prices to weekly prices set in relation to the market price.

Source: Bell et al., $2007 a$

\section{Box 12. Adjusting contracts: Postobon in Colombia}

One way to handle the problem of side-selling is through specific agreements that recognise opportunities and include them openly in negotiations. In Colombia, demand for tropical fruit pulp exceeds supply. As a result, the private sector firm Postobon began offering annual contracts to smallholder blackberry farmers that contained two market-condition related clauses. In times of high market prices (a seller's market), producers were allowed to sell up to 20 per cent of their total volume to other buyers principally for the fresh market. In times of low market prices (a buyer's market), Postobon was allowed to purchase up to 20 per cent of its total volume from non-contracted suppliers. These agreements explicitly recognised the pressure for opportunistic behaviour and identified mechanisms to manage them.

Source: Espinal et al., 2005

Frequent and consistent access to information on market trends, projected volumes and production technology, in addition to shared decision-making in regards to chain rules and price structures, is also critical. Better forecasting and planning can reduce some of the pressures on suppliers that drive poor working practices and casualisation of labour.

There are also models of 'inclusive procurement', built on preferential sourcing from small-scale producers and family farmers and their organisations. For example, Carrefour Indonesia has established a dialogue with SME suppliers of fresh food (vegetables and fish), household equipment and textiles, to improve product quality and packaging and improve their shelf access, in part by waiving the listing fee normally charged to companies waiting to sell to the chain. Similarly Wal-Mart, Honduras has established the 'Una Mano para Crecer' ('Help to Grow') programme for SMEs.

A commitment to inclusive procurement should include examining alternatives to paternalistic supply systems and demands of supplier exclusivity. While it is tempting to want to "cut out the middleman", chain intermediaries are often vital in linking smallholders to dynamic markets, and are of particular importance to the poorest farmers and to those located further away from the markets and the main roads. There is much for food processors and retailers to do to cultivate efficient intermediaries, including those set up through producers' own initiatives rather than seeking to eliminate them from the chain.

\section{Better standards}

The issue of private sector standards is also central to pro-smallholder business models. GLOBALGAP is now a passport to the most demanding export markets, but many compliance costs are not a function of the volume of production, but are per-farm costs, thus pushing up the per unit cost of compliance for small-scale producers. This applies as much to standards for 'sustainability' as to those for food safety and traceability. A 
lack of coordination between schemes means farmers certified to multiple standards must pay for separate audits. There are pro-smallholder approaches to standards, including group certification and combined audits, as well as the use of local certification agencies. But more fundamental is the participatory development of standards, involving the farmers who will have to implement them - the 'standards takers' - from the outset.

\title{
Pan-industry initiatives
}

Not all aspects of business models are competitive. Much can be achieved through industry collaboration to create an environment for more inclusive markets. Crossindustry codes of conduct established by the business sector and regulated by them, for example in Argentina (Box 13), can provide much needed oversight of trading relationships at the domestic level.

\begin{abstract}
Box 13. Best Commercial Practices Code in Argentina
Rapid investment by global and regional retail players in Argentina in the late 1990s created fierce competition with local retail investors, creating a trading environment unsatisfactory to small companies, a poor bargaining position for many and complaints at all levels. The choice faced by the sector was either to develop a private code or to submit to government legislation. The Food and Beverages Manufacturing Association (COPAL) and the Argentine Supermarkets Chamber (CAS) worked together with reference to evidence and experience from across the globe, to develop a private code of practice which was signed in June 2000. Since then supplementary rules have been added and the approach shared with many countries in the region and indeed worldwide. Similar private sector codes have, for example, been developed and adopted in Colombia and Mexico. Seven years on, there has been significant improvement in both free and fair practice and thus competitiveness. The culture and way of doing business has changed, with a dramatic decline in cases submitted for mediation or arbitration.
\end{abstract}

Source: Brom (2007)

\section{What are the priorities for the public sector?}

Innovative business models can make a positive difference in terms of inclusion. The role of public policy is not a primary focus of this paper. But it is important to note the potential of proactive policies - including infrastructure, finance and support services - to stimulate and support those types of business models which are more inclusive and also make good business sense. There is a vitally important role for the public sector to facilitate successful alliances between smallholders and larger business, especially if successful small initiatives are to be scaled up.

\section{The enabling environment}

A priority area of intervention is that of the enabling environment. Recent work by the World Bank on agricultural innovation systems identifies a range of options to support an enabling environment that promotes innovation. Key findings from this work include the importance of using targeted public and private research investments to resolve technological bottlenecks in the supply chain, the inclusion of social and environmental sustainability criteria, a focus on outcomes in terms of poverty reduction and a focus on collaboration among actors as a driver of competitiveness (World Bank, 2006). The consistent provision of key infrastructure services (roads, water, electricity and communications) is a central element of an enabling environment, as are relevant public policies to maintain a competitive market, to oversee the working of contract laws and contractual enforcement, and to oversee FDI and taxation. 
Investment in traditional and wholesale markets is clearly an important priority for public policy. When wholesale markets fail to keep up with changes in retail - especially the supermarket revolution - they can fall into decay. Traditional markets can be a bridge for small-scale farmers to increase their capacity and to eventually link to modern markets. Successful upgrading and modernisation of wholesale markets and their procurement networks also requires upgrading and modernising of their primary clients - the traditional retail sector - if they are to remain crucial players favouring inclusion of smallscale producers.

Where land is unequally distributed, as in South Africa, this becomes a significant determinant of market inclusion as the modern market will always seek to source from the large farm sector. Under these conditions of dualistic farm structure, inclusion attempts will be working against gravity, and public policy has a vital role.

Donors are increasingly interested in facilitating the bridge between the majority of smallscale producers and modern markets. Businesses can develop effective initiatives in partnership with governments, donors and NGOs, and can learn as much from the successes and failures of development agencies and NGOs as the latter can learn from business. For example, the cash \& carry operator METRO is working with the Viet Nam Ministry of Trade and the German development agency, GTZ, to support development of Viet Nam's distribution network. However, until these donor-supported initiatives are scaled up and become self-supporting, the question of tokenism and long-term sustainability remains. As an alternative approach, a number of donors have in place business challenge funds. The Africa Enterprise Challenge Fund, the Financial Deepening Challenge Fund, and the USAID Global Development Alliance offer the opportunity for innovative business models within inclusive agrifood markets to be both explored and developed.

At some point governments must balance equity and efficiency, despite the compelling case to support the huge numbers of small- and micro-scale farms. The costs of inclusion and exclusion must be evaluated when considering policy options. Evaluation of future scenarios should attempt to include estimates of these costs in order to provide additional insights into the real costs and benefits of the policy options. Case study evidence suggests that inclusion into restructured markets may be unsustainable for the "poorest of the poor". There is a lack of data to inform resource allocation and thus for example the threshold for support. Such thresholds can be a minimum size of farms, but may also include non-land triggers such as completion of training, or membership of a producer organisation.

\section{Partnership facilitation and chain-wide learning}

A key pattern in successful linkages between small-scale farmers and dynamic markets is the collaborative arrangement between (a) trained and organised farmers, (b) a receptive business sector, and (c) conducive public policies and programmes (Figure 2). Such arrangements may benefit from specialised partnership facilitation. Innovation in building inclusive markets is greatly enhanced when business actors within the market chain engage along the whole chain, together with indirect businesses (input suppliers, etc.) and with relevant public institutions. If interventions are made without coordination, they can lead to market distortions instead of market development, potentially flooding markets and supporting inefficient production systems. 
Figure 2. Foundations of sustainable market linkages between small-scale producers and agribusiness

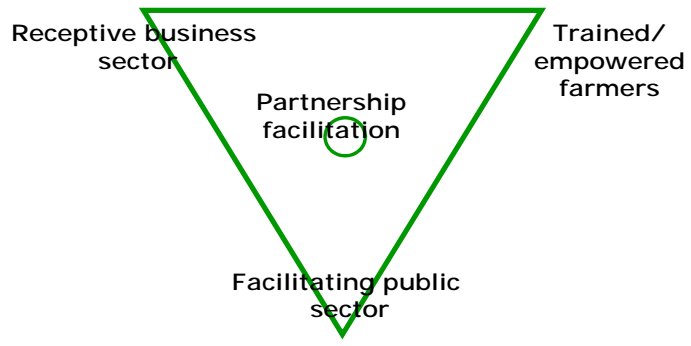

Source: Berdegué et al., 2008

The development of collaboration among actors requires linking actors in ways that facilitate discussions and information exchange among them. Examples of how this can work include chain-wide committees facilitated by Ministries of Agriculture, "interprofessional" or commodity associations formed by the chain partners (Shepherd and Cadilhon, forthcoming), and the use of Public-Private Partnerships. Difficult issues such as power and knowledge asymmetries need to be carefully managed to avoid excluding weaker members of the chain. Examples include work in Colombia ${ }^{10}$ and Honduras, as well as a link between the Centre for Agricultural Policy and Agribusiness Studies (CAPAS) at Padjadjaran University, Indonesia and Carrefour Indonesia. A memorandum of strategic co-operation between the two involves developing a supply chain model including small-scale suppliers, development of new agricultural products, transfer of know-how, and channelling of products to the Carrefour quality line programme.

\section{Encouraging procurement from small- and family-scale farmers}

Apart from providing an enabling environment and appropriate services, there are examples of specific policy innovations to encourage procurement from small and familyscale farmers:

- The biofuels Social Seal in Brazil is a promising example of a tool to improve the equity of the "biofuels revolution" by providing the downstream biodiesel industry with incentives to source their feedstock from smallholders and family farmers (Abramovay and Magalhães, 2007);

- Private-public partnerships in Michoacán, Mexico have been organised to coordinate the production and marketing of avocados, built around phytosanitary standards (Medina and Aguirre, 2007);

- The use of policy pressure or incentives for agribusiness and retail for pro-poor procurement, such as requiring supermarkets to provide adequate space in their shelves for small-scale farmers' products; and

- A supplier ombudsman with an independent regulatory role to oversee the way in which powerful buyers such as supermarkets engage with their suppliers, has been established in Australia.

\footnotetext{
${ }^{10}$ http://www.agrocadenas.gov.co
} 


\section{Closing comments}

There is a sound business case for securing and enhancing small-scale producers' inclusion, which can bring both economic as well as wider development gains. This requires that appropriate business models are applied and, where applicable, that this is done in partnership with producers, the public sector, intermediaries and development agencies. Two big challenges are evident when seeking to apply inclusive models to developing country economies dominated by small-scale producers, either for domestic retailing and processing, or for exporting. The first is organising and upgrading supply from a dispersed producer base. The second is traceability and quality assurance. Through attention to the 'partner network' in the business model framework (Figure 1), the value proposition of modern agrifood business and cost structure can be maintained or even strengthened by building in inclusion of small-scale producers and suppliers.

Successful models tend to evolve towards a common set of principles (Hobbs et al., 2000). These include: 1) greater information and knowledge flows; 2) a focus on differentiated products; 3) an orientation towards market demands; and, 4) chain-wide organisational structures that recognise the interdependence of actors and facilitate collaborative problem solving. The sum of these principles is 'systemic competitiveness', which is based not only on the efficiencies of individual actors but also on their collective efficiencies. The classic business model schematic in Figure 1, which describes the individual firm, therefore needs to be revisited to reflect how chain actors can collaborate to build a chain-wide model that balances risk, responsibilities, and benefits along the chain while not undermining competitiveness.

The business models concept is especially useful in helping business to understand the reach of downstream decisions on how value is created or lost by supply chain actors, including smallholders. But business models that work for more inclusive market development are not exclusively about procurement. The approach compels us to look to effective alliances and linkages by all chain participants. This rarely occurs spontaneously, given the often adversarial relationships that characterise commercial links in the agrifood sector. As a result, specific actions to clarify and develop plans for collective action at the chain scale are needed. Some good tools can be found in participatory chain analysis and upgrading manuals (Lundy et al., 2006; Vermeulen et al., 2008).

Another benefit of the business models concept is that it forces us to rethink CSR. The contemporary approach to CSR, with its emphasis on supplier codes and compliance, has been marginal to the issue of addressing the position of primary producers. Imposing pro-poor and inclusive procurement on suppliers, with the usual tools of supplier standards and compliance, will not bring about more inclusive markets. Nevertheless, there is a valid debate in rural development about the relative contribution of smallholder production versus plantation wage labour to the rural economy and to poverty reduction. Many wage labourers are the 'poorest of the poor', whom the OECDDAC refer to as Rural World 4 and Rural World 5 (OECD, 2006). The approaches to CSR and business and development have themselves diverged, with 'ethical' being focused on compliance approaches to labour standards, while 'fair' focuses on smallscale producers.

Another debate is between the importance of 'modern' markets and 'traditional' markets. Many of the models developed around modern restructured chains apply equally well to local and 'traditional' markets. Some emerging modern markets are extremely small, niche and donor-influenced, and a distraction from the priorities of broad-based rural development. Furthermore, even very progressive modern procurement systems can be exclusionary. Producers, intermediaries, buyers and support agencies must evaluate 
their options very carefully; there may be better rewards in the traditional markets, thanks to the high volume and less stringent standards. We need to know more about the applicability of new business models to trade with traditional markets.

This leads to the importance of acknowledging the risks of the 'new business model' concept. It is an open question as to whether new business models will benefit the poorest, and, if they do, whether they will ever be sustainable. Over-reliance on markets, coupled with voluntary pro-poor initiatives by business, misses the point of market governance, whereby genuinely effective business models work best in a strongly supportive policy environment, both for producers who want to connect to those chains and also for those who cannot. Policy attention will always be required to prevent persistent and engrained abuse of power in asymmetric power relations. Business models do not resolve other key issues such as infrastructure investments that may be critical to upgrade excluded producers. These 'hidden costs of inclusion' are not well accounted for in business models, but failure to include them limits the effects of even the most progressive approaches on the rural economy. 


\section{References}

Abramovay, R. and Magalhães R. (2007). Innovative Practice Brazil: Brazil Access of family farmers to biodiesel markets - partnerships between large companies and social movements. Regoverning Markets Innovative Practice series, IIED, London.

www.regoverningmarkets.org

Agropyme (2006). Innovaciones Organizacionales de Pequeños Productores de Vegetales para Participar en Canales de Comercialización Dinámicos en Honduras". Report prepared for the Regoverning Markets Consortium. Agropyme, Agencia Suiza para el Desarrollo y la Cooperación (COSUDE) and Swisscontact, Tegucigalpa, Honduras.

Aramyan, L., Ondersteijn, C., van Kooten, O., Oude Lansink, A. (2006). 'Peformance Indicators in Agri-Food Production Chains'. in C.J.M. Ondersteijn, J.H.M. Wijnands, R.B.M. Huirne and O. van Kooten (eds.), Quantifying the agri-food supply chain, 47-64. Springer, the Netherlands.

Bell, D.E., Milder, B. and Shelman, M. (2007). Vegpro Group: Growing in Harmony. Harvard Business School Case Study, December 2007.

Bell, D.E., Sanghavi, N., Fuller, V. and Shelman, M. (2007). Hariyali Kisaan Bazaar: A Rural Business Initiative. Harvard Business School Case Study, November 2007.

Berdegué, J. (2001). Cooperating to Compete - Associative Peasant Business Firms in Chile. PhD Thesis, Wageningen University.

Berdegué, J.A., Biénabe, E., and Peppelenbos, L. (2008a). Innovative Practice in Connecting Small-Scale Producers with Dynamic Markets. www.regoverningmarkets.org

Berdegué, J.A., Reardon, T., Hernández, R., Ortega, J. (2008b). Modern Market Channels and Strawberry Farmers in Michoacán, Mexico: Micro study report. Regoverning Markets Programme. http://www.regoverningmarkets.org

Bachev, H. and Manolov, I. (2007). Bulgaria: Inclusion of small-scale dairy farms in supply chains: a case from Plovdiv region. Regoverning Markets Innovative Practice series, IIED, London. www.regoverningmarkets.org

Bienabe, E., and Vermeulen, H. (2007). New trends in supermarket procurement systems in South Africa: the case of local procurement schemes from small-scale farmers by rural-based retail chain stores. Regoverning Markets Innovative Practice series, IIED, London.

Bouma, Jerry. (2005). Value Chain Workshop: Background, Methods and Management Principles. China-Canada Agricultural Development Program. First Training session of Changing Agri-Food Markets, Canada, 9-30 July. http://www.ccag.com.cn/downloads/training/train agrifood market/1st/eng/\%5Beng\%5D Value Chain Workshop.ppt 
Brom, Jorge, 2007. Best Commercial Practice Code (2000-2006) as an efficient policy innovation to prevent conflict and solve controversies between suppliers, processors and supermarkets. Regoverning Markets Innovative Policy Series, IIED, London.

Cadilhon J. (2006). Trading partners self-developing market linkages: Mr Van's lettuce supply chain to HCM City (Viet Nam). Presentation to FAO/VECO Workshop on enhancing capacities of NGOs and farmer groups to link farmers to markets, Bali, Indonesia, 9-12 May 2006.

http://www.fao.org/ag/ags/subjects/en/agmarket/linkages/Bali/Cadilhon.pdf

Camacho, P., Marlin, C., Zambrano, C. (2007). Elementos orientadores para la gestión de empresas asociativas rurales. Plataforma RURALTER, Mesa de trabajo en Desarrollo Económico, Quito, Ecuador, March.

CIAT and CIPASLA (2006). Proyecto "Mejorando los Servicios locales de apoyo en Cauca (Colombia) y Yorito (Honduras): Informe del Estudio de la Fase I. Project document presented to NZAID.

CIPS and Traidcraft (2008). Taking the lead: $A$ guide to more responsible procurement practices. Chartered Institute of Purchasing and Supply and Traidcraft. www.traidcraft.co.uk/international development/policy work/purchasing practices

Concepcion, S.B., Digal, L. and Uy, J. (2006). Keys to inclusion of small farmers in the dynamic vegetable market: The case of Normin Veggies in the Philippines. Regoverning Markets Innovative Practice Series, IIED, London. www.regoverningmarkets.org

Davies, R. (2007). The Trouble with Supermarkets - A Way Forward. March 2, 2007. http://www.seeingthepossibilities.com/?p=33

Eaton, C. and Shepherd, A.W. (2001). 'Contract farming. Partnerships for growth'. FAO Agricultural Services Bulletin 145. Rome.

Espinal, C.F., Martínez Covaleda, H.J., Peña Marín, Y. 2005. La Industria Procesadora de Frutas y Hortalizas en Colombia. Ministerio de Agricultura y Desarrollo Rural, Observatorio de Agrocadenas, Bogotá, October. 52 pages.

FAO and CIFOR (2002). Towards equitable partnerships between corporate and smallholder partners: Relating partnerships to social, economic and environmental indicators. http://www.fao.org/DOCREP/005/Y4803E/y4803e00.htm\#TopOfPage

FAO (2008). Contract Farming Resource Centre. http://www.fao.org/ag/ags/contractfarming

Garside, B., Vorley, B., and MacGregor, J. (2007). Miles better? How 'fair miles' stack up in the sustainable supermarket. Sustainable Development Opinion Paper, IIED. http://www.iied.org/pubs/display.php?o=17024IIED\&n=5\&l=45\&s=SDO

Gupta, R. (2008). New Models and Innovation in India: The Hariyali experience. Presentation to the conference "Inclusive Business in Agrifood Markets: Evidence and Action" Beijing, March 5-6, 2008.

www.regoverningmarkets.org/en/filemanager/active?fid $=828$ 
Hart, S.L. (2007) Capitalism at the Crossroads: The Unlimited Business Opportunities in Solving the World's Most Difficult Problems. Wharton School Publishing.

Hayami, Y. and Otsuka, K. (1993). The Economics of Contract Choice: An Agrarian Perspective. Clarendon Press.

Hellin, J., Lundy, M., and Meijer, M. (2007). Farmer organization, collective action and market access in Meso-America. CAPRi Working Paper No. 67, CGIAR Systemwide Program on Collective Action and Property Rights, Washington, DC, October.

Hobbs, J.E., Cooney, A., Fulton, M. (2000). Value chains in the Agri-Food Sector: What are they? How do they work? Are they for me? Specialized Livestock Market Research Group, College of Agriculture, Department of Agricultural Economics, University of Saskatechewan, Saskatoon, Canada.

Hu, D and Xia, D (2007). China: Case studies of Carrefour's quality lines. Regoverning Markets Innovative Practice Series, IIED, London. www.regoverningmarkets.org

Lemeilleur, S. and Tozanli, S. (2006). A Win-Win Relationship between Producers' Unions and Supermarket Chains in Turkish Fresh Fruits and Vegetables Sector. Paper presented at the International Seminar USAID Regional Consultation on linking farmers to Markets. Cairo, Egypt, 28 January - 3 February 2006.

http://eumed-agpol.iamm.fr/html/publications/partners/lemeilleurtozanli.pdf

Lundy, M. and S. Fujisaka. (2008). Prototipo de un ecosistema de negocios: Evaluación de la línea de productos SPA de Mabeli S.A. en Totonicapán. Informe Final. Sustainability Insitute, Comisión Presidencial para el Desarrollo Local, CDRO, PNUD y PRONACOM, Ciudad de Guatemala, mayo, 62 p.

Lundy, M. (2007). 'New Forms of Collective Action by Small-Scale Growers'. Input for the World Development Report 2008. Santiago, Chile: Rimisp. (http://www.rimisp.org/getdoc.php?docid=9855).

Lundy, M., Gottret, M.V., Best, R., and Ferris, R.S.B. (2006). A guide to evaluating and strengthening rural business development services. Field Manual. Centre Internacional de Agricultura Tropical (CIAT), Cali, Colombia.

Mafuru, J.M., Babu, A.K. and. Matutu, T.F. (2007). Tanzania: Impact of market links on horticultural production in the Mara region. Regoverning Markets Innovative Policy Series. www.regoverningmarkets.org

Medina, R., and Aguirre, M. (2007). Strategy for the inclusion of small and medium-sized avocado producers in dynamic markets as a result of phytosanitary legal controls for fruit transport in Michoacán, Mexico. Regoverning Markets Innovative Policy Series, IIED, London.

New York Times (2006). 'A Coffee Connoisseur on a Mission: Buy High and Sell High', The New York Times, 22 June 2006.

Ochoa, L., Lundy, M. (2001). El caso de producción de pasta de ají para exportación en el Valle del Cauca, Colombia. Prepared for FAO Latin American Regional Office as 
part of the 'Estrategia de Alianzas para el Desarrollo de Cadenas Productivas' Project. October 2001.

http://www.fao.org/Regional/LAmerica/prior/desrural/agroindustria/pdf/pastaji.pdf

OECD (2006). Promoting Pro-poor Growth: Agriculture. www.oecd.org/dac/poverty

Prahalad, C.K. and Hart, S.L (2002). 'The Fortune at the Bottom of the Pyramid'. Strategy+Business 26: 54-67

Reardon, T and Huang, J. (2008). Patterns in and Determinants and Effects of Farmers' Marketing Strategies in Developing Countries. Synthesis Report: Micro Study. www.regoverningmarkets.org

Samaratunga, P. A. (2007). Sri Lanka: Innovative practice in integrating small farmers into dynamic supply chains: a case study of MA's Tropical Food Company. Regoverning Markets Innovative Practice Series, IIED, London. www.regoverningmarkets.org

Sandredo (2006). 'The Dynamics of Supermarket Supplier'. Presentation to FAO Vredeseilanden Sub Regional Seminar on Enhancing Capacity of NGOs and Farmers Groups in Linking Farmers to Markets, Bali, May 9-12, 2006.

http://www.fao.org/ag/Ags/subjects/en/agmarket/linkages/Bali/bimandiri.pdf

Shepherd, A (2007). Approaches to Linking Producers to Markets. FAO Rural Infrastructure and Agro-Industries Division, Rome. http://www.fao.org/ag/ags/subjects/en/agmarket/linkages/agsf13.pdf

Shepherd, A and Cadilhon, J-J. (in preparation). Commodity associations: A tool for chain development? FAO Rural Infrastructure and Agro-Industries Division, Rome.

Shudon, Z. (2008). China: An example of an agricultural brokers' association: The Tongzhou Agricultural Broker Association. Nanjing Agricultural University. Regoverning Markets Innovative Practice Series, IIED, London. www.regoverningmarkets.org

Stringfellow, R., Coulter, J., Lucey, T., McKone, C. and Hussain, A. (1997). 'Improving the Access of Smallholders to Agricultural Services in Sub-Saharan Africa: Farmer cooperation and the role of the Donor Community'. ODI Natural Resource Perspectives, Number 20, June 1997.

Tallontire, A. and Vorley, B. (2005). Achieving fairness in trading between supermarkets and their agrifood supply chains. UK Food Group, London. www.ukfg.org.uk

Van der Vorst, J.G.A.J. (2006). 'Performance Measurement in Agri-Food Supply-Chain Newtorks: An overview'. in C.J.M. Ondersteijn, J.H.M. Wijnands, R.B.M. Huirne and O. van Kooten (eds.), Quantifying the agri-food supply chain,13-24. Springer. the Netherlands.

Vermeulen, S., Woodhill, J., Proctor, F. and Delnoye, R. (2008). Chain-wide learning for inclusive agrifood market development. IIED and Wageningen International.

Vorley B (2004). Food, Inc.: corporate concentration from farm to consumer. UK Food Group, London. www.ukfg.org.uk

WBCSD and SNV (2008). Negocios Inclusivos: Iniciativas Empresariales Rentables con Impacto en el Desarrollo. World Business Council for Sustainable Development (WBCSD) and SNV Netherlands Development Organization. www.inclusivebusiness.org 
Wiboonpongse, A., Sriboonchitta, S. and Khuntonthong, P. (2007) Innovative Management Leading Housewives' Group into Potato Supply Chain in Thailand. Regoverning Markets Innovative Practice series, IIED, London.

World Bank (2006). Enhancing Agricultural Innovation: How to Go Beyond the Strengthening of Research Systems. World Bank, Washington DC.

World Bank (2007a). Horticultural producers and supermarket development in Indonesia. World Bank, 2007. Report No. 38543-ID.

http://siteresources.worldbank.org/INTINDONESIA/Resources/Publication/2800161168483675167/Holtikultura en.pdf

World Bank (2008). World Development Report 2008: Agriculture for Development. World Bank, Washington DC. 


\section{Suggested selected web resources}

\begin{tabular}{|l|l|}
\hline $\begin{array}{l}\text { Empowering Smallholder } \\
\text { Farmers in markets (ESFIM) }\end{array}$ & www.esfim.org \\
\hline FAO Linking Farmers to Markets & www.fao.org/ag/Ags/subjects/en/agmarket/linkages/index.html \\
\hline $\begin{array}{l}\text { Inter-agency website for the } \\
\text { exchange of information on } \\
\text { value chains, linkages and } \\
\text { service markets }\end{array}$ & www.bdsknowledge.org \\
\hline $\begin{array}{l}\text { Making Markets Work Better for } \\
\text { the Poor project (Viet Nam, } \\
\text { Cambodia, Laos) www.markets4poor.org }\end{array}$ \\
\hline $\begin{array}{l}\text { Regoverning Markets } \\
\text { programme }\end{array}$ & www.regoverningmarkets.org \\
\hline $\begin{array}{l}\text { Sustainable Food Lab } \\
\text { Traidcraft - purchasing practices }\end{array}$ & $\begin{array}{l}\text { wwww.sustainablefood.org } \\
\text { policy_work/purchasing_practices }\end{array}$ \\
\hline $\begin{array}{l}\text { WBCSD-SNV Alliance on } \\
\text { Business Solutions for } \\
\text { Development }\end{array}$ & www.inclusivebusiness.org \\
\hline
\end{tabular}




\section{Business models that are inclusive of small farmers}

This paper was prepared for the Food and Agriculture Organization of the United Nations (FAO) and the United Nations Industrial Development

Organization (UNIDO) as background to the Global Agro-Industries Forum which took place in New Delhi from 8 to 11 April 2008. The paper describes a range of business models for inclusive market development within the context of agrifood restructuring and modernisation. It focuses specifically on models that improve the inclusiveness, fairness, durability and financial sustainability of trading relationships between small farmers on one hand and downstream agribusiness (processors, exporters and retailers) on the other. It also alerts us to the needs of external providers, such as financiers and training agents. 